\title{
PENGARUH PEMBERIAN SENYAWA KCL TERHADAP PERTUMBUHAN KECAMBAH SORGUM (Sorghum bicolor (L.) Moench)
}

\author{
THE EFFECT OF GROUPING KCL COMPOUND TO GROWTH \\ CONTINUING SORGUM (Sorghum bicolor (L.) Moench)
}

\author{
Nur Isfa'ni', Tundjung T. Handayani², Yulianti², Zulkifli². \\ 1) Mahasiswa Program Studi Biologi, Fakultas Matematika Dan Ilmu Pengetahuan Alam Universitas \\ Lampung, E-mail: nurisfani@gmail.com. \\ 2) Staf Dosen Pengajar Jurusan Biologi, Fakultas Matematika Dan Ilmu Pengetahuan Alam Universitas \\ Lampung, Jln. Professor Doktor Ir. Sumantri Brojonegoro No.1 Gedong Meneng, Rajabasa, Kota \\ Bandar Lampung, Lampung, Indonesia.
}

\begin{abstract}
ABSTRAK
Sorgum merupakan salah satu jenis tanaman serealia yang mempunyai potensi besar untuk dikembangkan di Indonesia. Namun masih banyak budidaya tanaman sorgum yang di tanam di lahan marginal, upaya peningkatan produktivitas tanaman sorgum tidak bisa hanya mengandalkan hasil yang ditanam pada lahan marginal saja, untuk itu perlu ada nya penambahan unsur hara berupa Kalium dalam meningkatkan produktivitas tanaman sorgum. Unsur $\mathrm{K}$ yang bersifat dinamis sehingga mudah tercuci perlu ditambahkan dalam bentuk senyawa $\mathrm{KCl}$. Penelitian ini bertujuan untuk mengetahui pengaruh senyawa $\mathrm{KCl}$ dan konsentrasi yang efektif dari senyawa $\mathrm{KCl}$ pada pertumbuhan kecambah sorgum. Peneitian ini dilaksanakan bulan November-Desember 2017 di Laboratorium Botani Jurusan Biologi Fakultas Matematika dan IImu Pengetahuan Alam Universitas Lampung. Peneitian ini menggunakan Rancangan Acak Lengkap dengan 5 taraf konsentrasi sebagai perlakuan yakni : $0 \%$ (kontrol), $10 \%, 20 \%, 30 \%$, dan $40 \%$. Variabel yang diamati yaitu tinggi tanaman, berat kering tanaman, klorofil a, klorofil b dan klorofi total. Data yang diperoleh di homogenitaskan dengan uji lavenne setelah homogen di analisis dengan analisis ragam (ANARA) pada $\alpha 5 \%$ jika terdapat perbedaan yang nyata maka akan dilakukan uji lanjut dengan uji beda nyata jujur (BNJ) pada $\alpha$ $5 \%$. Hasil penelitian menunjukkan senyawa $\mathrm{KCl}$ memberikan pengaruh terhadap pertumbuhan tanaman sorgum, pengaruh yang terlihat nyata hanya pada variabel rasio tunas akar sedangkan variabel lainnya memberikan pengaruh yang sama. Dan terdapat pemberian senyawa $\mathrm{KCl}$ yang efektif yaitu pada konsentrasi $10 \%$ yang terlihat jelas pada variabel rasio tunas akar tanaman sorgum.
\end{abstract}

Kata Kunci : Sorgum (Sorghum bicolor (L.) Moench), Unsur Hara, Senyawa KCl.

\begin{abstract}
Sorghum is one type of cereal plants that have great potential to be developed in Indonesia. But there is still a lot of cultivation of sorghum planted on marginal land, efforts to increase the productivity of sorghum can not only rely on the results planted on marginal land only, for it needs to have the addition of nutrients in the form of potassium in improving the productivity of sorghum plant. The K element which is dynamic so easily washed needs to be added in the form of a $\mathrm{KCl}$ compound. This study aims to determine the effect of $\mathrm{KCl}$ compounds and the effective concentration of $\mathrm{KCl}$ compounds on the growth of sorghum sprouts. This study was conducted November-December 2017 at the Botanical Laboratory of Biology Department Faculty of Mathematics and Natural Sciences University of Lampung. This study uses a Completely Randomized Design with 5 levels of concentration as treatment: $0 \%$ (control), 10\%, 20\%,30\%, and $40 \%$. The variables observed were plant height, plant dry weight, chlorophyll a, chlorophyll $b$ and total chlorophyll. Data obtained in homogeneity with lavenne test after homogeneous in analysis with analysis of variance (ANARA) at $\alpha 5 \%$ if there is real difference then will be tested continued with test of real difference honest (BNJ) at a $5 \%$. The results showed that $\mathrm{KCl}$ compound had an effect on the growth of sorghum plant, the effect that was visible only on the variables of shoot root ratio while other variables gave the same effect. And there is an effective $\mathrm{KCl}$ compound that is at $10 \%$ concentration that is clearly visible on the ratio of root buds of sorghum.
\end{abstract}

Keywords: Sorghum (Sorghum bicolor (L.) Moench), Nutrient Element, KCl Compound 


\section{PENDAHULUAN}

Sorgum (Sorghum bicolor (L.) Moench) merupakan salah satu tanaman bahan pangan penting di dunia. Kebanyakan produksinya digunakan sebagai bahan makanan, minuman, makanan ternak, dan kepentingan industri. Tanaman sorgum merupakan sumber karbohidrat yang mudah dibudidayakan (Wahida, 2011). Selain sebagai sumber karbohidrat, sorgum memiliki kandungan lainnya. Sorgum memiliki kandungan protein, mineral, dan vitamin yang lebih tinggi dibanding beras dan jagung sehingga tanaman sorgum sangat potensial sebagai bahan pangan utama (Narsih dkk, 2012). Sirappa (2003) menyatakan bahwa Sorgum merupakan salah satu jenis tanaman serealia yang mempunyai potensi besar untuk dikembangkan di Indonesia karena mempunyai sejumlah keunggulan diantaranya daya adaptasi agroekologi yang luas, tahan terhadap kekeringan dan genangan air, lebih tahan terhadap hama dan penyakit serta dapat bereproduksi pada lahan marginal. Upaya peningkatan produktivitas tanaman sorgum, tidak bisa hanya menggantungkan diri pada hasil sorgum yang ditanam di lahan marginal, tetapi tanah yang mengandung unsur hara yang baik memiliki peluang yang dapat dikembangkan sebagai penunjang pertumbuhan sorgum. Untuk itu perlu adanya penambahan unsur hara guna menunjang pertumbuhan sorgum. Salah satu unsur hara yang diperlukan adalah kalium.

Menurut Taufiq (2002), pada lahan yang kurang asupan hara akan terjadi defisiensi $\mathrm{K}$, hal itu disebabkan unsur $\mathrm{K}$ cenderung terkonsentrasi pada lapisan tanah atas sehingga sangat mudah tercuci. Menurut Novizan (2005), kalium diserap tanaman dari tanah dalam bentuk ion $\mathrm{K}^{+}$. Ion $\mathrm{K}^{+}$ bersifat dinamis sehingga mudah tercuci pada tanah berpasir dan tanah dengan $\mathrm{pH}$ rendah. Untuk mengatasi hal tersebut unsur $\mathrm{K}$ didukung dengan unsur lain yaitu $\mathrm{Cl}$ sehingga membentuk senyawa $\mathrm{KCl}$ (Kalium Clorida). Unsur K berfungsi sebagai media transportasi yang membawa unsur hara dari akar ke daun dan mentranslokasi asimilat dari daun ke seluruh jaringan tanaman. Kurangnya hara $\mathrm{K}$ dalam tanaman dapat menghambat proses transportasi dalam tanaman (Taufiq, 2002). Oleh sebab itu karena sangat pentingnya unsur $\mathrm{K}$ ini, maka dalam penelitian ini akan dilakukan penggunaan senyawa $\mathrm{KCl}$ untuk melihat pertumbuhan kecambah tanaman sorgum.

Tujuan dari penelitian adalah sebagai berikut :

1. Untuk mengetahui pengaruh pemberian senyawa $\mathrm{KCl}$ terhadap pertumbuhan kecambah sorgum.

2. Untuk mengetahui konsentrasi $\mathrm{KCl}$ yang efektif dalam mempengaruhi pertumbuhan kecambah sorgum.

\section{Metode Penelitian}

Penelitian ini akan dilaksanakan dari bulan November sampai dengan Desember 2017 di Laboratorium Botani Jurusan Biologi, Fakultas Matematika dan IImu Pengetahuan Alam, Universitas Lampung.

Penelitian ini dilakukan dengan menggunakan metode Rancangan Acak Lengkap dimana larutan senyawa $\mathrm{KCl}$ sebagai faktor utama dengan 5 taraf konsentrasi sebagai perlakuan yakni, $0 \%$ (kontrol), $10 \%, 20 \%$, 30\%, dan $40 \%$. Setiap perlakuan akan dilakukan 5 pengulangan maka jumlah satuan percoban yang diperoleh adalah 25. Tata letak satuan percobaan dengan menggunakan metode RAL 5 perlakuan dan 5 ulangan. Setiap satuan percobaan adalah 5 biji sorgum yang disemai 
13 / Isfa'ni N., Handayani T. T., Yulianti, Zulkifli.

dalam media tanam berisi tanah dan kompos pada masing-masing polybag $3 \mathrm{~kg}$.

Variabel yang diamati adalah tinggi tanaman, berat kering tanaman, klorofil a, klorofil b, dan klorofil total. Data yang diperoleh akan dianalisis dengan analisis ragam pada $\alpha 5 \%$ jika terdapat perbedaan akan dilakukan uji lanjut dengan uji beda nyata jujur (BNJ) pada a $5 \%$ untuk melihat perbedaan antar perlakuan.

\section{Hasil dan Pengamatan}

\section{Tinggi Tanaman}

Berdasarkan uji BNJ a 5\% menunjukan bahwa pemberian perlakuan senyawa $\mathrm{KCl}$ terhadap tinggi tanaman (cm) sorgum (sorghum bicolor L.) dapat dilihat pada Tabel 1 dibawah ini.

Tabel 1. Rata-rata tinggi tanaman $(\mathrm{cm})$ sorgum (Sorgum bicolor L.) yang telah diberi perlakuan pemberian larutan senyawa $\mathrm{KCl}$ selama 40 hari.

\begin{tabular}{cc}
\hline $\begin{array}{c}\text { Konsentrasi } \\
\text { (\% b/v) }\end{array}$ & $\begin{array}{c}\text { Tinggi Tanaman (cm) } \\
\overline{\mathbf{y}} \pm \mathrm{SE}\end{array}$ \\
\hline $\mathbf{0 \%}$ (kontrol) & $15.78 \pm 0.83^{\mathrm{a}}$ \\
$\mathbf{1 0 \%}$ & $16.06 \pm 0.74^{\mathrm{a}}$ \\
$\mathbf{2 0} \%$ & $14.84 \pm 0.84^{\mathrm{a}}$ \\
$\mathbf{3 0} \%$ & $15.56 \pm 3.53^{\mathrm{a}}$ \\
$\mathbf{4 0 \%}$ & $15.90 \pm 0.96^{\mathrm{a}}$ \\
\hline
\end{tabular}

Dari uji lanjut BNJ a 5\% menunjukkan bahwa pada perlakuan kontrol $(0 \%)$ memberikan pengaruh yang sama dengan konsentrasi $10 \%, 20 \%, 30 \%$, dan $40 \%$ artinya tidak ada perbedaan antar perlakuan. Hal tersebut terjadi karena di duga unsur-unsur yang dibutuhkan sudah tercukupi dari media tanam yang mengandung unsur-unsur hara. Dalam hal ini banyak faktor lain yang mendominasi dari pada pemberian senyawa $\mathrm{KCl}$ itu sendiri yaitu media tanam. Dimana media tanam itu diberikan dengan takaran yang sama dan kandungan unsur hara yang sama tidak ada perbedaan sehingga akan menghasilkan tinggi tanaman yang sama. Menurut Fageria dan Gheyi (2009) faktor yang

mempengaruhi ketersediaan hara adalah media tanam yang diantara nya tanah dan kompos. Jika unsur kalium yang ada didalam tanaman sesuai dengan kebutuhan, maka unsur ini dapat meningkatkan pertumbuhan tanaman melalui peningkatan penyerapan air dan hara membentuk jaringan selulosa dan diperlukan untuk mengaktifkan enzim yang terlibat didalam pertumbuhan tanaman.

\section{Berat Kering}

Berdasarkan uji BNJ a 5\% menunjukan bahwa pemberian perlakuan senyawa $\mathrm{KCl}$ terhadap berat kering (mg) tanaman sorgum (sorghum bicolor L.) dapat dilihat pada Tabel 2 dibawah ini.

Tabel 2. Rata-rata berat kering tanaman (mg) sorgum setelah perlakuan pemberian larutan senyawa $\mathrm{KCl}$.

\begin{tabular}{cc}
\hline $\begin{array}{c}\text { Konsentrasi } \\
(\% \text { b/v) }\end{array}$ & $\begin{array}{c}\text { Berat Kering (mg) } \\
\overline{\mathbf{y}} \pm \text { SE }\end{array}$ \\
\hline $\mathbf{0 \%}$ (kontrol) & $1.19 \pm 0.17^{\mathrm{a}}$ \\
$\mathbf{1 0 \%}$ & $1.25 \pm 0.14^{\mathrm{a}}$ \\
$\mathbf{2 0 \%}$ & $1.35 \pm 0.17^{\mathrm{a}}$ \\
$\mathbf{3 0 \%}$ & $1.06 \pm 0.13^{\mathrm{a}}$ \\
$\mathbf{4 0 \%}$ & $1.51 \pm 0.26^{\mathrm{a}}$ \\
\hline
\end{tabular}

Dari uji lanjut BNJ a 5\% menunjukkan bahwa pada perlakuan kontrol (0\%) memberikan pengaruh yang sama dengan konsentrasi $10 \%, 20 \%, 30 \%$, dan $40 \%$ artinya tidak ada perbedaan antar perlakuan. Dari hasil tersebut senyawa $\mathrm{KCl}$ tidak bisa menunjukan suatu perbedaan yang signifikan terhadap berat kering tanaman sorgum walaupun pemberian senyawa $\mathrm{KCl}$ yang optimal dapat membantu dalam proses penguraian tanah dan penyediaan unsur hara yang diserap oleh akar menuju tanaman sehingga dapat mempengaruhi berat kering tanaman. Roidah (2013) menjelaskan bahwa pemberian senyawa organik bermanfaat dalam penyediaan unsur hara dan mengaktifkan mikroorganisme tanah. Unsur hara yang diserap oleh akar akan di translokasikan ke bagian 
tanaman vegetatif maupun generatif untuk memacu proses fotosintesis secara optimal sehingga dapat mempengaruhi berat kering tanaman.

\section{Rasio Tunas Akar}

Berdasarkan analisis ragam pada tarap nyata $\alpha$ $5 \%$ menunjukkan bahwa pemberian senyawa $\mathrm{KCl}$ memberikan pengaruh yang nyata terhadap rasio tunas akar tanaman sorgum. Uji lanjut yang dilakukan adalah uji tukey a 5\% dengan rata-rata sebagai berikut dapat di lihat pada Tabel 3.

Tabel 3. Uji tukey rata-rata rasio tunas akar sorgum setelah perlakuan selama 40 hari.

\begin{tabular}{|c|c|}
\hline $\begin{array}{c}\text { Konsentrasi } \\
(\% \text { b/v) }\end{array}$ & $\begin{array}{c}\text { Rasio Tunas Akar } \\
\qquad \bar{y} \pm S E\end{array}$ \\
\hline $0 \%$ (kontrol) & $3.73 \pm 0.28^{a b}$ \\
\hline $10 \%$ & $4.47 \pm 0.40^{\mathrm{b}}$ \\
\hline $20 \%$ & $1.97 \pm 0.42^{\mathrm{a}}$ \\
\hline $30 \%$ & $3.59 \pm 0.61^{a b}$ \\
\hline $40 \%$ & $2.33 \pm 0.44^{a}$ \\
\hline
\end{tabular}

Keterangan : angka-angka yang diikuti oleh huruf yang sama menunjukkan tidak berbeda nyata berdasarkan uji Tukey one way dengan taraf nyata $5 \%=(p<$ $0.005)=1.89$.

Dari uji lanjut BNJ a 5\% (Tabel 3) menunjukkan bahwa perlakuan kontrol $(0 \%)$ sama pengaruhnya dengan $20 \%, 30 \%$ dan $40 \%$. Sedangkan perlakuan kontrol (0\%) juga sama dengan $10 \%$ dan $30 \%$. Tetapi $10 \%$ tidak sama pengaruhnya dengan $20 \%$ dan $40 \%$. Sehingga dikatakan bahwa $10 \%$ adalah perlakuan yang efektif dibanding perlakuan $0 \%$, $20 \%, 30 \%$ dan $40 \%$. Hal tersebut karena rasio tunas akar adalah perbandingan antara berat kering tunas dan berat kering akar yang menunjukan suatu unsur simpanan atau unsur yang merupakan hasil fotosintat yang tersimpan, bukan berupa air karena air terlepas dan menguap karena dikeringkan. Hal tersebut karena ada hasil fotosintesis yang membutuhkan ion $\mathrm{K}$ dan $\mathrm{Cl}$.
Dengan adanya hasil fotosintat yang disuplaikan ke tunas dan akar maka pada konsentrasi $10 \%$ dapat menyerap unsur $\mathrm{K}$ dan $\mathrm{Cl}$ sehingga menunjukan pertumbuhan yang baik.

Hal tersebut sesuai pernyataan teori Fageria dkk, (2009) bahwa unsur K memegang peranan penting didalam metabolisme tanaman, kalium dibutuhkan dalam proses fotosintesis, fiksasi $\mathrm{CO} 2$ dan transfer fotosintat ke berbagai penjuru tanaman. Kebutuhan kalium diabsorbsi dalam bentuk $\mathrm{K}+$ dan dijumpai dalam berbagai kadar didalam tanah. Bentuk yang tersedia bagi tanaman biasanya terdapat dalam jumlah kecil. Kadar kalium yang cukup pada tanaman mengakibatkan normalnya pembentukan dan pembesaran ukuran sel pada tanaman. Terjadinya respon yang berbeda nyata karena meningkatnya laju proses fotosintesis dimana unsur kalium berperan dalam fotofosforilasi dalam proses fotosintesis.

\section{Klorofil a}

Berdasarkan uji BNJ a 5\% menunjukan bahwa pemberian perlakuan senyawa $\mathrm{KCl}$ terhadap klorofil a (mg/g.jaringan) tanaman sorgum (sorghum bicolor L.) dapat dilihat pada Tabel 4 dibawah ini.

Tabel 4. Rata-rata klorofil a (mg/g.jaringan) tanaman sorgum (Sorghum bicolor L.) setelah perlakuan pemberian larutan senyawa $\mathrm{KCl}$ umur 40 hari.

\begin{tabular}{cc}
\hline $\begin{array}{c}\text { Konsentrasi } \\
(\% \text { b/v) }\end{array}$ & Klorofil a (mg/g.jaringan) \\
\hline $\mathbf{0} \%$ control & $1.09 \pm 0.08^{\mathrm{a}}$ \\
$\mathbf{1 0 \%}$ & $1.21 \pm 0.07^{\mathrm{a}}$ \\
$\mathbf{2 0} \%$ & $1.09 \pm 0.04^{\mathrm{a}}$ \\
$\mathbf{3 0 \%}$ & $1.17 \pm 0.06^{\mathrm{a}}$ \\
$\mathbf{4 0 \%}$ & $1.30 \pm 0.08^{\mathrm{a}}$ \\
\hline
\end{tabular}


15 / Isfa'ni N., Handayani T. T., Yulianti, Zulkifli.

Dari uji lanjut BNJ a 5\% menunjukkan bahwa pada perlakuan kontrol $(0 \%)$ memberikan pengaruh yang sama dengan konsentrasi $10 \%, 20 \%, 30 \%$, dan $40 \%$ artinya tidak ada perbedaan antar perlakuan.

\section{Klorofil b}

Berdasarkan uji BNJ a 5\% menunjukan bahwa pemberian perlakuan senyawa $\mathrm{KCl}$ terhadap klorofil b (mg/g.jaringan) tanaman sorgum (sorghum bicolor L.) dapat dilihat pada Tabel 5 dibawah ini.

Tabel 5. Rata-rata klorofil b (mg/g.jaringan) tanaman sorgum (Sorghum bicolor L.) setelah perlakuan pemberian larutan senyawa $\mathrm{KCl}$ selama 40 hari.

\begin{tabular}{cc}
\hline $\begin{array}{c}\text { Konsentrasi } \\
(\% \text { b/v) }\end{array}$ & Klorofil b $\begin{array}{c}\text { (mg/g.jaringan) } \\
\overline{\mathbf{y}} \pm \mathbf{S E}\end{array}$ \\
\hline $\mathbf{0 \%}$ Kontrol & $0.54 \pm 0.04^{\mathrm{a}}$ \\
$\mathbf{1 0 \%}$ & $0.35 \pm 0.03^{\mathrm{a}}$ \\
$\mathbf{2 0 \%}$ & $0.48 \pm 0.05^{\mathrm{a}}$ \\
$\mathbf{3 0 \%}$ & $0.60 \pm 0.05^{\mathrm{a}}$ \\
$\mathbf{4 0 \%}$ & $0.43 \pm 0.15^{\mathrm{a}}$
\end{tabular}

Dari uji lanjut BNJ a 5\% menunjukkan bahwa pada perlakuan kontrol $(0 \%)$ memberikan pengaruh yang sama dengan konsentrasi $10 \%, 20 \%, 30 \%$, dan $40 \%$ artinya tidak ada perbedaan antar perlakuan.

\section{Klorofil Total}

Berdasarkan uji BNJ a 5\% menunjukan bahwa pemberian perlakuan senyawa $\mathrm{KCl}$ terhadap klorofil total (mg/g.jaringan) tanaman sorgum (sorghum bicolor L.) dapat dilihat pada Tabel 6 dibawah ini.
Tabel 6. Rata-rata klorofil total tanaman sorgum (Sorghum bicolor L.) setelah perlakuan pemberian larutan senyawa $\mathrm{KCl}$ selama 40 hari.

\begin{tabular}{cc}
\hline $\begin{array}{c}\text { Konsentrasi } \\
(\% \mathbf{b} / \mathbf{v})\end{array}$ & $\begin{array}{c}\text { Klorofil total (mg/g.jaringan) } \\
\overline{\mathbf{y}} \mathbf{\mathrm { SE }}\end{array}$ \\
\hline $\mathbf{0 \%}$ control & $1.63 \pm 0.07^{\mathrm{a}}$ \\
$\mathbf{1 0 \%}$ & $1.57 \pm 0.07^{\mathrm{a}}$ \\
$\mathbf{2 0} \%$ & $1.58 \pm 0.08^{\mathrm{a}}$ \\
$\mathbf{3 0} \%$ & $1.78 \pm 0.09^{\mathrm{a}}$ \\
$\mathbf{4 0 \%}$ & $1.73 \pm 0.18^{\mathrm{a}}$ \\
\hline
\end{tabular}

Dari uji lanjut BNJ a 5\% menunjukkan bahwa pada perlakuan kontrol $(0 \%)$ memberikan pengaruh yang sama dengan konsentrasi $10 \%, 20 \%, 30 \%$, dan $40 \%$ artinya tidak ada perbedaan antar perlakuan.

Pada klorofil a, klorofil b dan klorofil total tidak memberikan pengaruh yang nyata terhadap pemberian senyawa $\mathrm{KCl}$ pada tanaman sorgum. $\mathrm{Hal}$ tersebut terjadi karena walaupun $\mathrm{K}$ berfungsi untuk membantu transportasi unsur-unsur hara dan $\mathrm{Cl}$ yang berfungsi untuk mengikat molekul lipid dan protein pada membran sehingga protoplasma akan tetap bertahan hidup selama pertumbuhan nya. Tetapi klorofil itu kebanyakan memerlukan unsur $\mathrm{N}$ dimana unsur $\mathrm{N}$ itu banyak tersedia di dalam media tanam. Media tanam tersebut diberikan dalam kondisi yang sama dan hasil akhir nya menunjukan klorofil a, klorofil b dan klorofil total dalam pemberian $\mathrm{KCl}$ nya memberikan pengaruh yang sama, sehingga $\mathrm{KCl}$ tidak berperan langsung dalam pembentukan klorofil.

Hal tersebut sesuai dengan teori Suntoro (2002) yang menyatakan bahwa pemberian senyawa $\mathrm{KCl}$ dapat meningkatkan ketersediaan dan serapan kalium, Kalium berperan penting dalam proses fotosintesis karena secara langsung meningkatkan pertumbuhan dan indeks luas daun sehingga 
meningkatkan asimilasi $\mathrm{CO} 2$ serta meningkatkan translokasi dan asimilasi hasil fotosintesis. sementara fungsi $\mathrm{Cl}$ dalam kloroplas berperan sebagai penjaga $\mathrm{pH}$ dan menjaga protoplasma agar tetap hidup. Menurut sutedjo (2002) kalium sebenarnya sangat diperlukan pada lahan kering, karena pada tanah ini banyak kation $\mathrm{K}+$ yang hilang dan terangkut oleh tanah melalui pencucian air hujan. Pemberian senyawa kalium sekaligus tidak efektif karena hara-hara ini akan tercuci sebelum diserap tanaman. Sumadi (2007) menyatakan bahwa $\mathrm{K}+$ berperan dalam proses fisiologis dan biokimia tanaman dan diserap secara aktif dengan penyerapan yang tinggi. Kecepatan penyerapan $\mathrm{K}+$ dikontrol oleh $\mathrm{K}+$ yang terdapat di dalam sel dan berakibat pada turgor sel. Pada siang hari akan berlangsung fotosintesis yang menghasilkan energy untuk mendorong peningkatan penyerapan $\mathrm{K}+$ yang akhirnya akan meningkatkan konsentrasi $\mathrm{K}_{+}$dan menaikkan tekanan turgor. Defisiensi $K_{+}$berakibat pada penurunan laju pertumbuhan dan meningkatkan resistensi tanaman terhadap penyakit.

Dari penelitian tersebut diatas walaupun pemberian senyawa $\mathrm{KCl}$ pada tanaman sorgum (Sorghum bicolor L.) tidak memberikan pengaruh yang nyata terhadap variabel tinggi tanaman, berat kering total, klorofil $\mathrm{a}, \mathrm{b}$ dan klorofil total namun memberikan pengaruh yang nyata terhadap variabel rasio tunas akar dengan perlakuan yang efektif diperoleh pada konsentrasi 10\%. Maka pada penelitian ini dapat dikatakan bahwa pemberian senyawa $\mathrm{KCl}$ pada konsentrasi $10 \%$ berpengaruh nyata terhadap rasio tunas akar tanaman sorgum (Sorghum bicolor L.).

\section{KESIMPULAN}

1. Senyawa $\mathrm{KCl}$ memberikan pengaruh terhadap pertumbuhan tanaman sorgum. Pengaruh yang terlihat nyata hanya pada variabel rasio tunas akar sedangkan variabel lainnya sama pengaruhnya.

2. Terdapat pemberian senyawa $\mathrm{KCl}$ yang efektif yaitu pada konsentrasi $10 \%$ yang terlihat jelas pada variabel rasio tunas akar tanaman sorgum.

\section{SARAN}

Perlu penelitian lebih lanjut dalam mendukung hasil tersebut diatas, terutama dalam pemberian senyawa $\mathrm{KCl}$ dengan takaran yang optimum atau seimbang dalam menunjang pertumbuhan tanaman sorgum dan juga perlu dilakukan penelitian dengan variasi senyawa kimia lainnya untuk menghindari kekurangan atau kelebihan suatu unsur didalam senyawa tersebut.

\section{DAFTAR PUSTAKA}

Farhad, I.S,M., Islam, S. Hoque, and M.S.I. Bhuiyan. 2010. Role of Potassium and Shulpur on the Growth, yield, and Oil Content of Soybean (Glycine max L.). Ac. J. Plant Sci, 3(2):99-103. Bangladesh

Fargeria, NK., M.P.B. Filho, and J.H.C. Da Costa. 2009. Potassium in the Use of Nutrients in Crop Plants. CRC Press Taylor and Francis Group, Boca Raton, London, New YORK. 131-163.

Narsih, Yunianta and Harijono. 2012. The Study of Germination and Soaking Time to Improve nutritional quality of Sorghum seed. International Food Research Journal 19 (4): 1429-1432. Malang.

Novizan. 2005. Petunjuk Pemupukan yang Efektif. Agromedia Pustaka. Jakarta. $114 \mathrm{HIm}$. 
17 / Isfa'ni N., Handayani T. T., Yulianti, Zulkifli.

Roidah, I.S. 2013. Manfaat Penggunaan Pupuk Organik Untuk Kesuburan Tanah. Jurnal Universitas Tuluagung Bonorowo. 1(1):30-42.

Sirappa, M P. 2003. Prospek Pengembangan Sorgum di Indonesia Sebagai Komoditas Alternatif untuk Pangan, Pakan dan Industri. Jurnal Litbang Pertanian, 22(4). Makassar.

Sumadi. 2007. Nutrien Mineral. http://www.elearning.unej.ac.id. 7 hal.

Suntoro, W.A. 2002. Peranaan Bahan Organik Terhadap Kesuburan Tanah Dan Upaya Pengelolaannya. Universitas Sebelas Maret. Surakarta.

Sutedjo, M. M. 2002. Pupuk dan Cara Pemupukan. Rineka Cipta. Jakarta.

Taufiq, A. 2002. Status $P$ dan $K$ lahan kering tanah alfisol pulau Jawa dan Madura serta optimasi pemupukannya untuk tanaman kacang tanah. Prosiding Seminar Nasional dan Pertemuan Tahunan Komisariat Daerah Himpunan IImu Tanah Indonesia. 1617 Desember 2002. Hal. 94-103. Malang.

Wahida. 2011. Karakterisasi Mutu Gizi Dan Diversifikasi Pangan Berbasis Sorgum (Sorghum vulgare). Balai Besar Penelitian dan Pengembangan Pasca Panen Pertanian. Bogor. 
--- this page left blank --- 